Article

\title{
Geo-Heritage Specific Visibility as an Important Parameter in Geo-Tourism Resource Evaluation
}

\author{
Anna V. Mikhailenko ${ }^{1}$ (D) and Dmitry A. Ruban $2,3, *$ (D) \\ 1 Department of Physical Geography, Ecology, and Nature Protection, Institute of Earth Sciences, \\ Southern Federal University, Zorge Street 40, Rostov-on-Don 344090, Russia; avmihaylenko@sfedu.ru \\ 2 Department of Economics and Management, Business School, Cherepovets State University, \\ Sovetskiy Avenue 10, Cherepovets, Vologda Region 162600, Russia \\ 3 Department of Business in Hospitality Sphere, Higher School of Business, Southern Federal University, \\ 23-ja linija Street 43, Rostov-on-Don 344019, Russia \\ * Correspondence: ruban-d@mail.ru
}

Received: 10 March 2019; Accepted: 24 March 2019; Published: 27 March 2019

\begin{abstract}
Geological heritage (geo-heritage) is a resource for geoscience, geo-education, and geo-tourism. Geo-tourist attractions differ in their physical visibility, interpretation (clarity), and aesthetic attractiveness. These three characteristics determine perception of visitors and, thus, the importance of attractions. An integrative parameter, namely specific visibility, is proposed for qualitative geo-tourism resource evaluation. This parameter is examined for all geo-heritage types, and some relevant examples from southwest Russia are considered. The geo-heritage types differ in their specific visibility. For instance, when landforms like the Granite Gorge in the Western Caucasus (geomorphological type) are well-visible, geochemical processes like the heavy metal cycling in the Don River delta and the Pelenkino mud lake (geo-chemical type) are not as visible. Such a difference should be taken into account when geo-tourism resources of any area or a geopark are evaluated. The lower the specific visibility, the higher the costs for professional interpretation and demand for advanced infrastructure solutions.
\end{abstract}

Keywords: aesthetic properties; interpretation; karst; mercury; mud lake; Western Caucasus; Don River delta

\section{Introduction}

Geological heritage (geo-heritage) is a unique geological phenomena. The conceptual basis for the relevant judgments has been summarized recently by Reynard and Brilha [1]. Geo-heritage management is provided by individual interest groups, institutions, and major international organizations, such as ProGEO and the UNESCO Global Geopark network. Geo-heritage has been recognized recently as an important resource bringing socio-economic benefits. The relevant ideas are conceptualized in the works of Ali and Unjah [2], Bétard et al. [3], Ehsan et al. [4], Habibi et al. [5], Ibáñez et al. [6], Muda and Tongkul [7], Ruban [8], Wang et al. [9], and Wu and Xiang [10]. Much attention has been paid to the identification of geo-heritage that is understood as a resource by definition. In fact, in order to recognize any natural element as a resource, its general societal utility should be argued. Geo-heritage has value to scientists needing appropriate objects for research, educators needing explanation of some basic knowledge to students and their training, and tourists interested in learning more about the nature. If so, three kinds of geo-heritage resources can be recognized, namely geoscience resources, geo-education resources, and geo-tourism resources (Figure 1). From these, the latter are of special economic importance because geoparks and other geology-related attractions bring direct profit, as well as facilitating the entire tourism industry growth because of diversification of tourism 
products and services. The exploitation of the geo-heritage resource deepens people's understanding of the natural environment's complexity and fragility and, thus, contributes to the development of ecologically-responsible behavior. The creation of geo-parks diversifies leisure possibilities and offers new jobs.

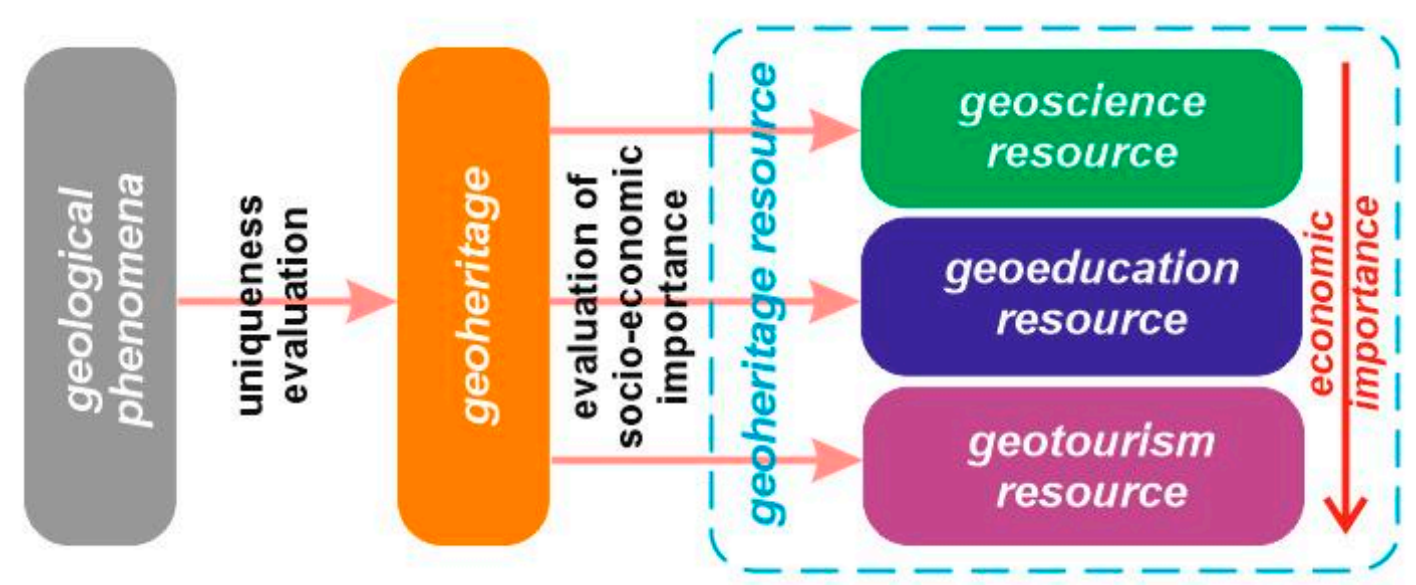

Figure 1. Basic processes and components of geoheritage resource evaluation.

The efficient exploitation of each natural resource requires accurate evaluation, particularly in finding properties that make the resource really valuable. Geo-tourism has grown actively since the 2000s [1,11-17]. This tendency has established together with the rise of the international and national geopark initiatives [18-20]. In such conditions, new geo-tourist attractions seem to be in demand, and, thus, the principles of selection of geo-heritage objects for their creation need to be clarified. Evidently, the only high unique geological phenomena is not enough. The understanding of this uniqueness is often limited by the almost total absence of even elementary geological knowledge among the majority of visitors. Although this problem can be fixed with professional interpretations of the geological information (guided excursions, specially installed panels and kiosks, interactive and virtual tools, etc.) $[13,21-25]$, the relevant solutions limit carrying capacity of geo-tourist attractions and require additional costs for geo-tourism resource exploitation. Moreover, tourists can be better satisfied from visits to geo-parks, offering easier-to-understand geo-heritage. If so, some unique geological features are more valuable than others, depending on how people without professional knowledge can perceive them. An indirect confirmation of this issue is the dominance of easy-to-understand geomorphological heritage (i.e., unique landforms) in the existing global geoparks [8]. The importance of panoramic sites for geo-heritage observation argued by Migoń and Pijet-Migoń [26] also implies an urgency of geo-heritage clarity and geology-dominated landscape admiration to tourists.

The main objective of the present paper is the introduction of geo-heritage-specific visibility as one of the key parameters in geo-tourism resource evaluation. It is intended to relate this parameter to different types of geo-heritage, as well as to demonstrate the differences in this parameter with some representative examples, that have been studied by the authors in two areas of southwest Russia.

\section{Terminological and Methodological Notes}

The visual appearance of geo-heritage is commonly thought to be a criterion of its evaluation [27,28]. Frequently, this criterion is understood with certain difference and limitations. For instance, Warowna et al. [29] recognized the colour of geological features as the main aesthetic property, and Costantini and L'Abate [30] proposed a distinction between visibility, exposure, and observability. Undoubtedly, a systematic treatment of the visual appearance of geo-heritage is necessary.

The perception of geo-heritage is a complex process that refers to three characteristics of the observable objects, namely unmasked physical visibility, a need in professional interpretation, and aesthetic attractiveness. Physical visibility depends on whether tourists can observe a given geological 
object directly. This aspect is important because of the possibility to determine the very essence of each tourist attraction. For instance, bivalve shells can be observed in a palaeontological locality, whereas another locality distinguished by unusual geochemical processes does not permit these processes to be observed because of their appearance at the level of chemical compounds and the low speed. Clivaz and Reynard [31] coined the term invisible geomorphosites that describes unique landforms that do not longer exist, but remain interesting to visitors. It should be noted that vegetation or debris cover, location geometry, and infrastructure objects can prohibit adequate observation of a unique object. However, such situations are locality-dependent and should be ignored when the general category of geo-heritage is discussed. Thus, it is sensible to judge the unmasked physical visibility, which means visibility of the geological phenomenon itself, irrespective of its manifestation in a given case. In other words, this term can be employed in geo-heritage-related judgments in the case of ideal exposure. A Need in professional interpretation is a characteristic of geo-tourist attractions, reflecting its self-clarity. Tourist satisfaction strongly depends on whether she/he can easily understand the attraction or not [13]. For instance, a waterfall will be detected as a waterfall by its visitors, whereas a globally-important stratotype representing boundary between two successive geological eras will not be understood as such without special explanation to the majority of visitors. Finally, the aesthetic attractiveness of a unique phenomenon means the degree of its correspondence to the tourists' idea of beauty. Undoubtedly, a beautiful tourist site makes a site more attractive (and this also makes tourist experience more enjoyable) [13]. Although such an idea may differ significantly, there are some universal criteria for individual and group judgments of what is beautiful and what is not [32-34].

Unmasked physical visibility, which is needed in professional interpretation and aesthetic attractiveness differ essentially, but these are also strongly related to one another, and these characteristics jointly determine the perception of geo-heritage by potential tourists. These characteristics make unique phenomena more or less visible to visitors. If so, it is sensible to introduce the integrative term, namely specific visibility, which reflects how easily geo-heritage features can be seen by unprepared tourists (Figure 2). The word visibility is preferred over clarity because the latter refers to the need for interpretation. Geo-heritage specific visibility seems to be one of the key parameters in geo-heritage resource evaluation. Its importance decreases in the case of geo-tourists with professional knowledge and 'trained eyes', i.e., those who do not depend on interpretation and knowing what, where, and how to see. However, the majority of geo-tourists remain unprepared (e.g., [13]).
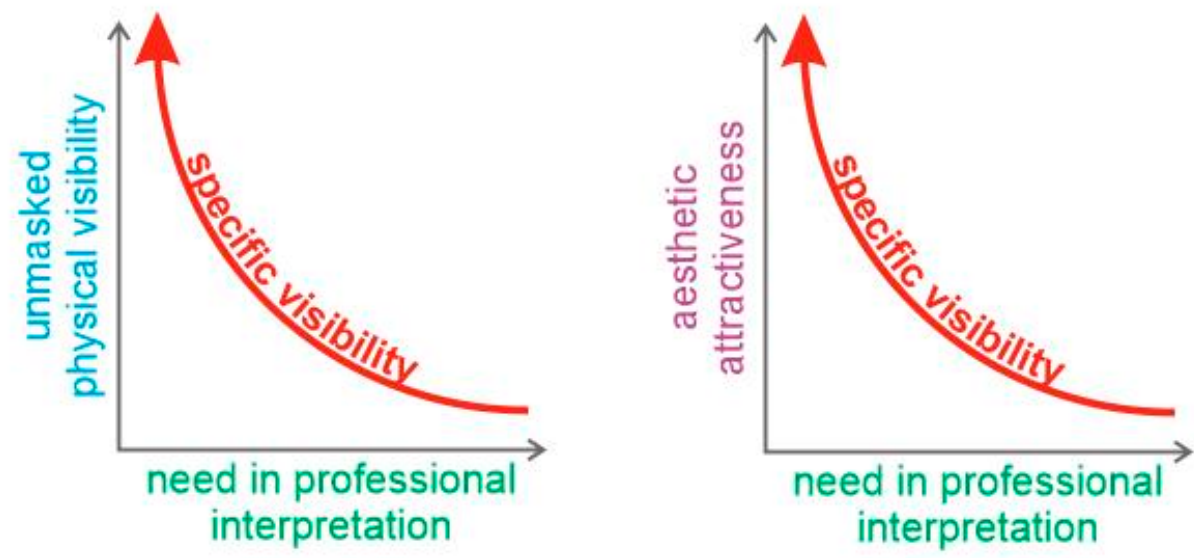

Figure 2. Dependence of geo-heritage specific visibility on the other characteristics of geo-tourist attractions.

Specific visibility depends on many conditions and factors (often local-e.g., the presence of vegetation cover or slope debris, locality geometry, infrastructure, etc.), but it is sensible to understand whether unique geological phenomena (taken in 'ideal' state) differ in this parameter. If these differ, there is a differing importance of these phenomena as geo-tourism resources. Such a general knowledge would be very desirable at the stage of resource evaluation. For instance, this allos predictions to be 
made of visitor flow, anticipating costs for resource exploitation (e.g., for professional interpretation), and to judge which geological phenomena should be included in the planned geo-tourist attraction and to increase its value.

There are different classifications of unique geological phenomena (e.g., [35-38]). In this paper, the classification proposed by Ruban [38] and refined by Habibi et al. [5] is used (the other classifications can be further employed for the specific visibility analysis by the principle explained below). Geo-heritage types reflect the main classes of all known geological phenomena, as representatives of these classes can be unique under certain circumstances. A total of 21 types are distinguished. The essence of each relevant class of geological phenomena is analyzed in order to conclude about common specific visibility. The approach is conceptual (real examples are not considered to avoid influence local specific features, although such examples are used for testing the results-see the Discussion section), as follows. A very typical feature, representing a given class, is considered (for instance, the igneous geo-heritage type would be best represented by an outcrop of granites). Then, it is judged on whether this feature is physically visible (if locally unmasked), whether it needs interpretation for unprepared visitors, and whether it matches some universal criteria of beauty. Importantly, the possible links between the three characteristics are traced where possible. For instance, the paleogeography type, which represents the information about the ancient environments and ecosystems, and these features existed in the only past and cannot be seen in the present-day rock outcrops (only indirect physical visibility); strong professional interpretation is necessary to realize these [39]. The beauty is doubtful without such an interpretation. Such judgments resemble expert assessment, but these are based on objective (not subjective) criteria.

In order to trace the differences between the geo-heritage types by the analyzed parameter, the four categories of specific visibility are distinguished, namely high specific visibility (HSV; i.e., full visibility), moderate specific visibility (MSV; i.e., certain deficiencies in either unmasked physical visibility, or the need for professional interpretation, which can be recompensed partly by high aesthetic attractiveness), limited specific visibility (LSV; i.e., significant problems with seeing and/or understanding unique features), and specific invisibility (ISV; i.e., total invisibility, chiefly because of physical invisibility). For some types, specific visibility can vary depending on the relevant phenomena, and, thus, this variation is also taken into consideration.

\section{Results}

Geo-heritage types really differ in their specific visibility (Table 1). Most common are the types characterized by MSV (41\%). The types with HSV are also quite common (27\%). ISV is established in $18 \%$ of cases. The least frequent are the types with LSV constituting only $14 \%$. As specific visibility is thought to be an important determinant of geo-tourism resource value, the localities with palaeontological (fossils), mineralogical (minerals), geothermal (geysers), geomorphological (landforms), hydrological (geological activity of water), and geohistorical (sites of famous geological discoveries) should be identified as the most important for creation of geo-tourist attractions. These localities will be easily perceived by visitors and the costs for interpretation of infrastructure will be minimal. The examples of localities representing geo-heritage types with different specific visibility are given below (see Discussion).

The information on geoparks in seven countries boasting the biggest number of these tourist attractions implies that the most common geo-heritage types are geomorphological, paleontological, igneous, sedimentary, and palaeogeographical [8]. These types represent the specific visibility categories, except for ISV (Table 1). Supposing that the noted types comprise the most abundant geo-tourist attractions (not necessarily geoparks), it is possible to conclude that the available world geo-heritage demonstrates more or less significant specific visibility, i.e., it is a really valuable geo-tourism resource. However, a reversal interpretation is also sensible. It can be understood that, most probably, the geological features, with high or moderate specific visibility, are recognized more commonly than 
less-visible phenomena of the other types. In such a case, the entire world geo-heritage resource is limited because of the biased approaches of its recognition.

Table 1. Specific visibility of geo-heritage types.

\begin{tabular}{ccc}
\hline Geo-heritage Type [5] & Specific Visibility (Most Common) & Specific Visibility Variation \\
\hline Stratigraphical & LSV & Low \\
Palaeontological & HSV & Moderate \\
Sedimentary & MSV & Low \\
Igneous & MSV & Low \\
Metamorphic & MSV & Low \\
Mineralogical & HSV & Moderate \\
Economical & MSV & Moderate \\
Geochemical & ISV & Low \\
Seismical & LSV & Low \\
Structural & MSV & Moderate \\
Palaeogeographical & LSV & Low \\
Cosmogenic & MSV & High \\
Geothermal & HSV & Low \\
Geocryological & MSV & Low \\
Geomorphological & HSV & High \\
Hydrological/hydrogeological & HSV /ISV & High \\
Engineering & MSV & Moderate \\
Radiogeological & ISV & Low \\
Neotectonical & ISV & Low \\
Pedological & MSV & Low \\
Geohistorical & HSV & Moderate \\
\hline
\end{tabular}

Interesting, four geo-heritage types are attributed to the ISV category. The geochemical and radio-geological types are characterized by the very small scale and chiefly long-term processes in the geological environment. Regular measurements and laboratory analyses are necessary to conclude these processes, and, thus, these cannot be seen directly in the field. Hydrogeological phenomena cannot be observed because these take place underground. The only natural springs and boreholes are manifestations of this type on the surface. Finally, the neotectonical type represents in slow motion the surface because of current tectonic activity. These motions can be detected only as a result of long-term measurements (e.g., with satellite-based remote sensing technologies) and highly-specific geological observations. These four types seem to be the least valuable in terms of geo-tourism resource or, rather, their exploitation for tourism will require significant investments in interpretation infrastructure and development of really advanced, innovative interpretation solutions. For instance, the demonstration of any peculiar geochemical process would require the installation of interactive panels or equipment for quick analyses of rocks, bottom deposits, and/or soils for the purpose of demonstrating the activities of this process. As for the palaeogeographical type, which may be thought invisible because of representation of ancient environments and ecosystems, it appears to be sensible to attribute it not to the ISV category, but to LSV. This is because particular elements and attributes of past environments and ecosystems are visible in rock outcrops. For instance, these may include in-situ preserved fossil assemblages, specific rock color indicating palaeoclimate.

Two other geo-heritage types deserve attention. The cosmogenic type is represented, either by meteorites stored in museum collections, which are well-visible, although cannot be recognized as meteorites without any simple explanation (MSV), or impact craters. The latter often can be established only as a result of the interpretation of geological, geomorphological, and geophysical information. In the other words, it is really difficult to distinguish these craters in the field by typical landforms or geological material (ISV). The structural type, which is constituted by folds, faults, nappe structures, etc., is physically visible in the field, but understanding their geological essence requires professional interpretation. Nonetheless, these geological phenomena are distinguished by significant aesthetic 
attractiveness [33], which recompenses partly the noted unclarity. Additionally, viewpoint geo-sites (sensu Migoń and Pijet-Migoń [26]) facilitate the perception of structural uniqueness together with enjoying observation of panoramic views.

\section{Discussion}

This paper proposes a new parameter, namely geo-heritage specific visibility and the principle of its evaluation. The outcomes of this principle application to geo-heritage types are presented above. However, the validity of such an approach should be discussed in regard to its testing in the real world. The idea of geo-heritage type results from conceptualization, and, thus, the notions of specific visibility of each type presented above have to be discussed with some examples. The authors' field investigations in southwest Russia permit several real or potential geo-tourist attractions to be considered, five of which are located in the Western Caucasus (the geodiversity hotspot of Mountainous Adygeya [38]), and two other are located near the Azov Sea in the Rostov Region [40] (Table 2). These localities provide examples of all four categories of specific visibility.

Table 2. Basic characteristics of the geo-tourist attractions considered as case examples.

\begin{tabular}{|c|c|c|c|}
\hline Geo-tourist Attraction & Location & Uniqueness & Current use in Tourism \\
\hline Granite Gorge & $\begin{array}{c}\text { Western Caucasus, SW } \\
\text { Russia }\end{array}$ & National & $\begin{array}{l}\text { Active (gorge as a main } \\
\text { attraction) }\end{array}$ \\
\hline $\begin{array}{l}\text { Karst sinkhole in the } \\
\text { Lagonaki Highland }\end{array}$ & $\begin{array}{c}\text { Western Caucasus, SW } \\
\text { Russia }\end{array}$ & Local & $\begin{array}{l}\text { Occasional (observation by } \\
\text { rare by-pass tourist groups) }\end{array}$ \\
\hline $\begin{array}{l}\text { Folded Triassic rocks in } \\
\text { the Rufabgo Canyon }\end{array}$ & $\begin{array}{c}\text { Western Caucasus, SW } \\
\text { Russia }\end{array}$ & Global & $\begin{array}{l}\text { Active (waterfalls are the } \\
\text { main attractions, but not } \\
\text { geological features) }\end{array}$ \\
\hline $\begin{array}{c}\text { Jurassic deep-marine } \\
\text { shales near the Partisan } \\
\text { Glade }\end{array}$ & $\begin{array}{c}\text { Western Caucasus, SW } \\
\text { Russia }\end{array}$ & Local & None \\
\hline $\begin{array}{c}\text { Oshten Mountain-A } \\
\text { Late Jurassic reefal } \\
\text { massif }\end{array}$ & $\begin{array}{c}\text { Western Caucasus, SW } \\
\text { Russia }\end{array}$ & National & $\begin{array}{l}\text { Active (landscape and } \\
\text { ecosystems are the main } \\
\text { attractions, but not } \\
\text { geological features) }\end{array}$ \\
\hline Don River delta & $\begin{array}{c}\text { Rostov Region, SW } \\
\text { Russia }\end{array}$ & National & $\begin{array}{l}\text { Occasional (unregulated } \\
\text { outdoor recreation and } \\
\text { irregular ecotourism } \\
\text { activities) }\end{array}$ \\
\hline Pelenkino mud lake & $\begin{array}{c}\text { Rostov Region, SW } \\
\text { Russia }\end{array}$ & Local & $\begin{array}{l}\text { Active (unregulated outdoor } \\
\text { recreation and irregular } \\
\text { ecotourism activities) }\end{array}$ \\
\hline
\end{tabular}

The Granite Gorge is a deep gorge cut by the Belaya River in the Late Paleozoic granites and granodiorites of the Dakh Crystalline Massif. This is a peculiar, nationally-unique landform (geomorphological type of geo-heritage). Visitors can observe typical morphology of the gorge from several viewpoints. The unmasked physical visibility of the gorge is excellent, there is not any need in professional interpretation, and the aesthetic attractiveness is evidently high (Figure 3A). A road stretches along the gorge, and special places ('pockets') are constructed to leave a car and to enjoy panoramic views of the deep gorge. This locality can be attributed unequivocally to the HSV category, which is typical for the geomorphological type of geo-heritage (Table 2). Consequently, the Granite Gorge is thought to be a valuable geo-tourism resource, and it is not surprising that it is crowded by visitors. This is one of very few, really successful geo-heritage-based tourist attractions of southwest Russia, which are visited by thousands of tourists coming from the both nearby towns and other regions of Russia. 

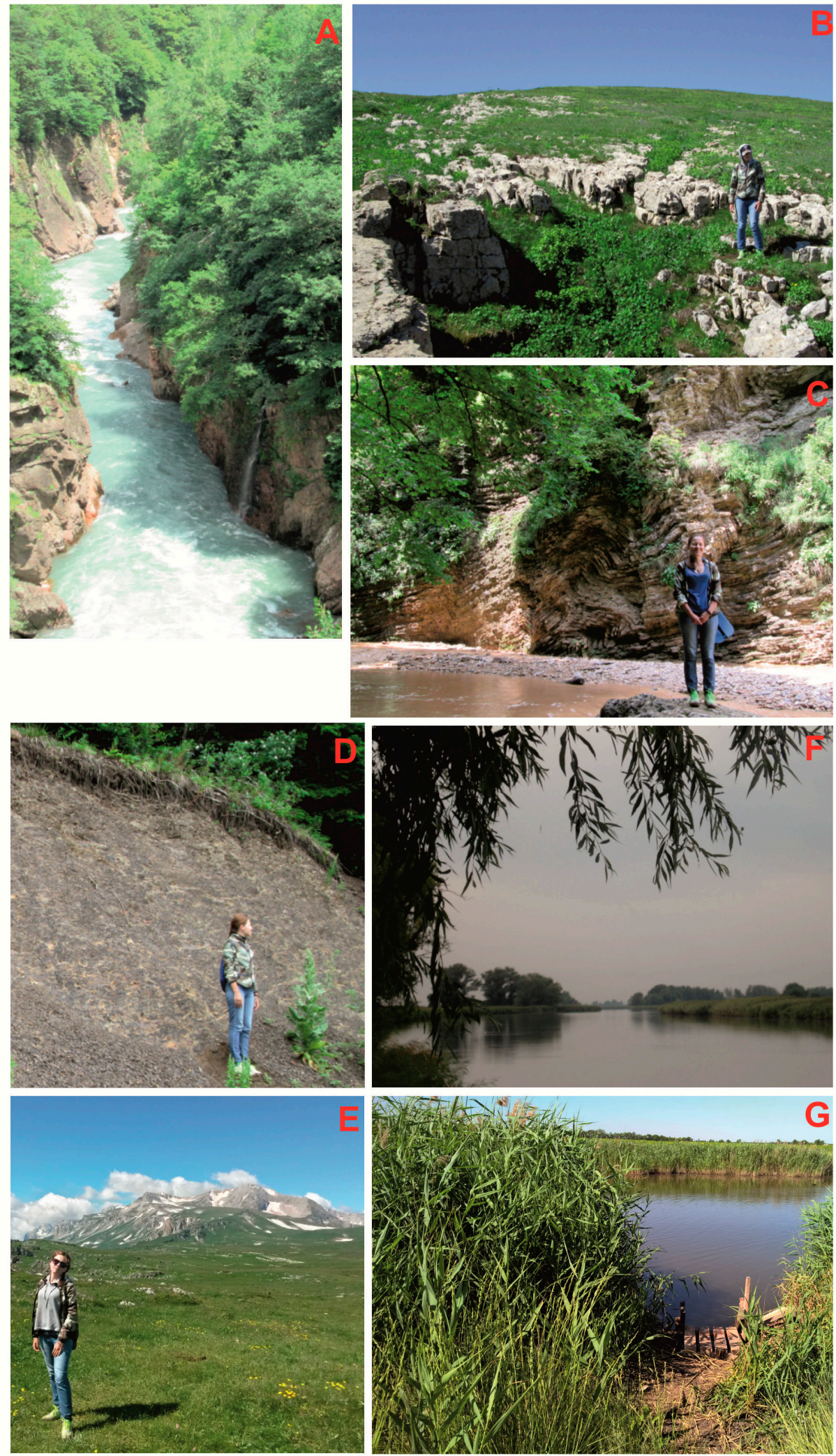

Figure 3. Geo-tourist attractions considered as case examples: (A) the Granite Gorge; (B) the karst sinkhole in the Lagonaki Highland; (C) the folded Triassic rocks in the Rufabgo Canyon; (D) the Jurassic deep-marine shales near the Partisan Glade; (E) the Oshten Mountain-a Late Jurassic reefal massif; (F) the Don River delta; $(\mathbf{G})$ the Pelenkino mud lake (created by the authors; the author (A.V.M.) stays for scale on b-e); see Table 2 for more information. 
The karst sinkhole in the Lagonaki Highland is a very typical epikarst feature formed as a result of carbonate rock dissolution on the area of significant rainfall. This is a locally-unique, small-scale landform (geomorphological type of geo-heritage). Visitors can walk around and observe it entirely (Figure 3B). The unmasked physical visibility is excellent, but some explanation of the essence of such features is required in order to perceive it correctly. Aesthetic attractiveness is unimportant in this case because strong and positive impressions of tourists are formed from visiting the entire highland area. With regard to the above-said, this locality can be attributed to the MSV category. This is different from the most common category of specific visibility of the geomorphological type of geo-heritage, and, thus, this example demonstrates that the specific visibility can vary within the same type (Table 2). This sinkhole seems to be a less valuable geo-tourism resource, and its inclusion in the programs of local excursions would require installation of the explanatory panel with a professional interpretation of the feature.

The folded Triassic rocks in the Rufabgo Canyon are exposed along the Rufabgo River (left tributary of the Belaya River), and these were formed because of orogenic compression or submarine slumping (or both). This structural feature is a part of a globally-unique geo-heritage. A popular excursion route stretches along natural outcrops with the folds. The unmasked physical visibility of the folds is perfect, but to understand their essence, without professional explanation, would be difficult for unprepared visitors; the aesthetic attractiveness is very significant because the folds look like natural geometry [33] (Figure 3C). Evidently, this locality has to be attributed to the MSV category, as well as the entire structural geo-heritage type (Table 2). The folded Triassic rocks of the Rufabgo Canyon constitute significant geo-tourism resource, but its exploitation will require either funding professionally guided excursions or the installation of explanatory panels.

The palaeogeographical type can be demonstrated in two features, namely the Jurassic deep-marine shales near the Partisan Glade, which represent the ancient deep sea with oxygen depleted-conditions, and the Oshten Mountan, which is a Late Jurassic reefal massif (i.e., it was part of the ancient barrier reef). The former can be visited by tourists (Figure 3D), and the latter is viewed from a distance of several kilometers for better comprehension (Figure 3E). The unmasked physical visibility is exceptional in the both cases. However, it is very difficult to relate the currently-observable features to the ancient environments; a very advanced professional interpretation is necessary. The dark color of shales (a common result of oxygen deficit in the seawater) and the morphology of the mountain (fossil reef) would facilitate this interpretation slightly. The aesthetic attractiveness is much higher in the case of the Oshten Mountain, but it does not recompense the lack of clarity of the palaeogeographical essence in this site. These localities are sensible to attribute to the LSV category, which is typical for the palaeogeographical type of geo-heritage (Table 2). Despite the evident geo-heritage value (especially in the case of the Oshten Mountain [39]), the discussed features have very limited geo-tourism resource value. The exploitation of these resources will require additional costs to resolve the problem with professional interpretation. Most probably, these localities suit only excursions of professional geologists, students, and some geology amateurs.

The Don River delta is a typical deltaic environment near the big city of Rostov-on-Don, representing interesting processes linked to mercury pollution, temporary storage, and removal by sea floods [40], as well as various processes linked to contamination by other heavy metals, organic compounds, and oil-related matter. This is a nationally-unique geochemical feature, which can be visited by nature-oriented tourists. However, potential tourists cannot observe geochemical processes directly. They can see only water objects and rich ecosystems (Figure 3F). Mercury cycling occurs in water, suspended matter, bottom sediments, and soils. This takes place at the level of chemical compounds, and its speed is slow. Sampling and laboratory analyses are necessary to realize the uniqueness of the geochemical phenomena. In the other words, the geo-heritage is totally invisible in this locality, and it should be attributed to the ISV category, which is characteristic to this type of geo-heritage (Table 2). The geo-tourism resource value of the Don River delta is significantly restricted, and the exploitation of this resource would require costly and non-standard interpretation solutions. 
The Pelenkino mud lake is tied genetically to the Don River delta. It represents the processes of sulfide mud formation. This is part of the local geo-heritage, and its main types are hydrological, sedimentary, and geochemical. Although visitors of this lake can observe the lake and mud itself (Figure 3G), some professional interpretation is necessary to explain the essence of the mud; the geochemical processes that lead to mud formation are totally invisible. The HSV category should be attributed to the hydrological type, the MSV category should be attributed to the sedimentary type, and the ISV category should be attributed to the geochemical type. These categories are characteristic for the relevant types (Table 2). In sum, this locality taken entirely is sensible to attribute to the MSV category. The geo-tourism resource value of the Pelenkino mud lake is somewhat restricted, and exploitation of this resource requires some professional support.

\section{Conclusions}

The undertaken study makes three main conclusions. First, geoheritage-specific visibility depends on physical visibility, the need for professional interpretation, and aesthetic attractiveness. These are important parameters in geotourism resource evaluation. Second, geoheritage types differ by specific visibility, which is important to consider when geotourism resources of any area or geopark are evaluated. Third, an analysis of real examples of geoheritage corroborates the usefulness of specific visibility as a geo-tourism resource parameter.

The parameter proposed in the present paper is treated as a tentative, qualitative manner. Broad consultations between theoreticians and practitioners in geotourism are necessary in order to strengthen the approach of its application. Undoubtedly, there may be some other parameters useful in geo-tourism resource evaluation, such as accessibility, the degree of vegetation/debris-masking, carrying capacity, etc. However, specific visibility seems to be a key parameter because it determines the possibility of the unique phenomena comprehension by visitors and, thus, their satisfaction from geo-tourist attractions. Moreover, the attention to specific visibility is necessary to improve strategies of geo-heritage promotion. Potentially, all kinds of geo-heritage can be interesting to the wide circle of people. If its visibility is considered properly, this emphasizes unique features that can attract visitor even with zero geological knowledge.

Author Contributions: Conceptualization, D.A.R.; original data collection, A.V.M.; methodology, D.A.R.; investigation, A.V.M. and D.A.R.; writing, D.A.R.

Funding: This research in the Don River delta was supported by the RF President grant MK6548.2018.5, agreement 075-02-2018-136 (contribution of A.V.M.). The research of the Pelenkino mud lake was supported by the grant of the Russian Science Foundation Project 17-17-01229 (contribution of A.V.M.). The D.A.R.'s contribution received no external funding.

Acknowledgments: The authors are grateful for the journal editorial team and both anonymous reviewers for their helpful recommendations and support.

Conflicts of Interest: The authors declare no conflict of interest.

\section{References}

1. Reynard, E.; Brilha, J. (Eds.) Geoheritage: Assessment, Protection, and Management; Elsevier: Amsterdam, The Netherlands, 2018; pp. 1-482.

2. Ali, C.A.; Unjah, T. The importance of geological heritage resources in land use planning: Experience from Langkawi Geopark. Plan. Malays. 2011, 9, 55-82. [CrossRef]

3. Bétard, F.; Hobléa, F.; Portal, C. Geoheritage as new territorial resource for local development. Ann. Geogr. 2017, 717, 523-543. [CrossRef]

4. Ehsan, S.; Shafeealeman, M.; Arabegum, R. Geotourism: A tool for sustainable development of geoheritage resources. Adv. Mater. Res. 2013, 622, 1711-1715. [CrossRef]

5. Habibi, T.; Ponedelnik, A.A.; Yashalova, N.N.; Ruban, D.A. Urban geoheritage complexity: Evidence of a unique natural resource from Shiraz city in Iran. Resour. Policy 2018, 59, 85-94. [CrossRef] 
6. Ibáñez, J.-J.; Brevik, E.C.; Cerdà, A. Geodiversity and geoheritage: Detecting scientific and geographic biases and gaps through a bibliometric study. Sci. Total Environ. 2019, 659, 1032-1044. [CrossRef]

7. Muda, J.; Tongkul, F. Geoheritage resources of the Baliajong River: Potential for geotourism development. Bull. Geol. Soc. Malays. 2008, 54, 139-145. [CrossRef]

8. Ruban, D.A. Geodiversity as a precious national resource: A note on the role of geoparks. Resour. Policy 2017, 53, 103-108. [CrossRef]

9. Wang, H.; Li, J.; Wu, T. Characteristics and Genesis of Geoheritage Resources of Taihang Mountain. Acta Sci. Nat. Univ. Pekin. 2018, 54, 546-554.

10. Wu, Y.-D.; Xiang, F. Evaluation of geoheritage resources in the "two mountains-and-one lake" area of Anhui, China. Geol. Bull. China 2007, 26, 231-240.

11. Allan, M.; Shavanddasht, M. Rural geotourists segmentation by motivation in weekends and weekdays. Tour. Hosp. Res. 2019, 19, 74-84. [CrossRef]

12. Dowling, R. Geotourism's Global Growth. Geoheritage 2011, 3, 1-13. [CrossRef]

13. Dowling, R.; Newsome, R. (Eds.) Handbook of Geotourism; Elwar Edgar Publishing: Cheltenham, UK, 2018; pp. 1-499.

14. Gordon, J.E. Geoheritage, geotourism and the cultural landscape: Enhancing the visitor experience and promoting geoconservation. Geosciences 2018, 8, 136. [CrossRef]

15. Hose, T.A. Towards a history of geotourism: Definitions, antecedents and the future. Geol. Soc. Lond. Spec. Publ. 2008, 300, 37-60. [CrossRef]

16. Ólafsdóttir, R.; Tverijonaite, E. Geotourism: A systematic literature review. Geosciences 2018, 8, 234. [CrossRef]

17. Ruban, D.A. Geotourism-A geographical review of the literature. Tour. Manag. Perspect. 2015, 15, 1-15. [CrossRef]

18. Henriques, M.H.; Brilha, J. UNESCO Global Geoparks: A strategy towards global understanding and sustainability. Episodes 2017, 40, 349-355. [CrossRef]

19. Justice, S.C. UNESCO global geoparks, geotourism and communication of the earth sciences: A case study in the Chablais UNESCO Global Geopark, France. Geosciences 2018, 8, 149. [CrossRef]

20. Nikolova, V.; Sinnyovsky, D. Geoparks in the legal framework of the EU countries. Tour. Manag. Perspect. 2019, 29, 141-147. [CrossRef]

21. Began, M.; Višnic, T.; Djokic, M.; Vasiljevic, D.A. Interpretation Possibilites of Geoheritage in Southeastern Serbia-Gorge and Canyon Study. Geoheritage 2017, 9, 237-249. [CrossRef]

22. Modrej, D.; Fajmut Štrucl, S.; Hartmann, G. Results of the geointerpretation research in the frame of the Danube GeoTour project. Geologija 2018, 61, 101-110.

23. Pacheco, J.; Brilha, J. The importance of interpretation for the diffusion of geoheritage: A review. Comun. Geol. 2014, 101, 101-107.

24. Rutherford, J.; Newsome, D.; Kobryn, H. Interpretation as a vital ingredient of geotourism in coastal environments: The geology of sea level change, Rottnest Island, Western Australia. Tour. Mar. Environ. 2015, 11, 55-72. [CrossRef]

25. You, Y.; Tian, M.; Yang, Y.; Gao, L. Construction of geoparks' interpretation system based on geoheritage protection. Wit Trans. Ecol. Environ. 2014, 189, 863-870.

26. Migoń, P.; Pijet-Migoń, E. Viewpoint geosites-Values, conservation and management issues. Proc. Geol. Assoc. 2017, 128, 511-522. [CrossRef]

27. Brilha, J. Inventory and Quantitative Assessment of Geosites and Geodiversity Sites: A Review. Geoheritage 2016, 8, 119-134. [CrossRef]

28. Reynard, E.; Perret, A.; Bussard, J.; Grangier, L.; Martin, S. Integrated Approach for the Inventory and Management of Geomorphological Heritage at the Regional Scale. Geoheritage 2016, 8, 43-60. [CrossRef]

29. Warowna, J.; Zgłobicki, W.; Kołodyńska-Gawrysiak, R.; Gajek, G.; Gawrysiak, L.; Telecka, M. Geotourist values of loess geoheritage within the planned Geopark Małopolska Vistula River Gap, E Poland. Quat. Int. 2016, 399, 46-57. [CrossRef]

30. Costantini, E.A.C.; L'Abate, G. The soil cultural heritage of Italy: Geodatabase, maps, and pedodiversity evaluation. Quat. Int. 2009, 209, 142-153. [CrossRef]

31. Clivaz, M.; Reynard, E. How to Integrate Invisible Geomorphosites in an Inventory: A Case Study in the Rhone River Valley (Switzerland). Geoheritage 2018, 10, 527-541. [CrossRef] 
32. Kirillova, K.; Fu, X.; Lehto, X.; Cai, L. What makes a destination beautiful? Dimensions of tourist aesthetic judgment. Tour. Manag. 2014, 42, 282-293. [CrossRef]

33. Mikhailenko, A.V.; Nazarenko, O.V.; Ruban, D.A.; Zayats, P.P. Aesthetics-based classification of geological structures in outcrops for geotourism purposes: A tentative proposal. Geologos 2017, 23, 45-52. [CrossRef]

34. Ruban, D.A. Aesthetic properties of geological heritage landscapes: Evidence from the Lagonaki Highland (Western Caucasus, Russia). J. Geogr. Inst. "Jovan Cvijić" Sasa 2018, 68, 289-296. [CrossRef]

35. Bradbury, J. A keyed classification of natural geodiversity for land management and nature conservation purposes. Proc. Geol. Assoc. 2014, 125, 329-349. [CrossRef]

36. Brocx, M.; Semeniuk, V. Geoheritage and geoconservation-History, definition, scope and scale. J. R. Soc. West. Aust. 2007, 90, 53-87.

37. Prosser, C.; Murphy, M.; Larwood, J. Geological Conservation: A Guide to Good Practice; English Nature: Peterborough, UK, 2018; pp. 1-145.

38. Ruban, D.A. Quantification of geodiversity and its loss. Proc. Geol. Assoc. 2010, 121, 326-333. [CrossRef]

39. Bruno, D.E.; Crowley, B.E.; Gutak, J.M.; Moroni, A.; Nazarenko, O.V.; Oheim, K.B.; Ruban, D.A.; Tiess, G.; Zorina, S.O. Paleogeography as geological heritage: Developing geosite classification. Earth-Sci. Rev. 2014, 138, 300-312. [CrossRef]

40. Mikhailenko, A.V.; Ruban, D.A. Geoheritage in Deltaic Environments: Classification Notes, Case Example, and Geopark Implication. Environments 2019, 6, 18. [CrossRef]

(C) 2019 by the authors. Licensee MDPI, Basel, Switzerland. This article is an open access article distributed under the terms and conditions of the Creative Commons Attribution (CC BY) license (http:/ / creativecommons.org/licenses/by/4.0/). 